\title{
https://doi.org/10.46813/2021-133-142 \\ ON GAS AND HYDRAULIC TIGHTNESS \\ OF LINAC ACCELERATING SECTIONS
}

\section{V.F. Zhiglo \\ National Science Center “Kharkov Institute of Physics and Technology”, Kharkiv, Ukraine E-mail: zhiglo@kipt.kharkov.ua}

A technique for calculating the required impenetrability of brazing linac accelerating sections cooled by water and for control of their hydraulic tightness based on the total helium leakage rate is given. Three types of cooling systems: a water stream in tubes soldered on the outer surface of the sections, a water stream along the outer surface and along the internal cooling channels in sections are considered. It is shown that the contact of accelerating sections surface with cooling water requires increasing the tightness of their soldering at least by 66 times. As an example, requirements for hydraulic and air tightness of accelerating sections for the developed accelerator LU-10 NSC KIPT are given.

PACS: 29.17.+w

\section{INTRODUCTION}

The temperature stabilization of the linac accelerating sections is carried out by two ways (Fig. 1): 1) by passing water through tubes soldered on the outer surface of the section [1] and 2) by flowing water along the outer surface [1] or the internal longitudinal channels in the section body [2, 3]. Method 2) provides better thermal contact with the coolant, however, it leads to the likelihood of water leak through soldered joints parts of the accelerating section.

Obviously, method 1) requires checking the air tightness of the section. Method 2), along with air tightness, also requires hydraulic water tightness.
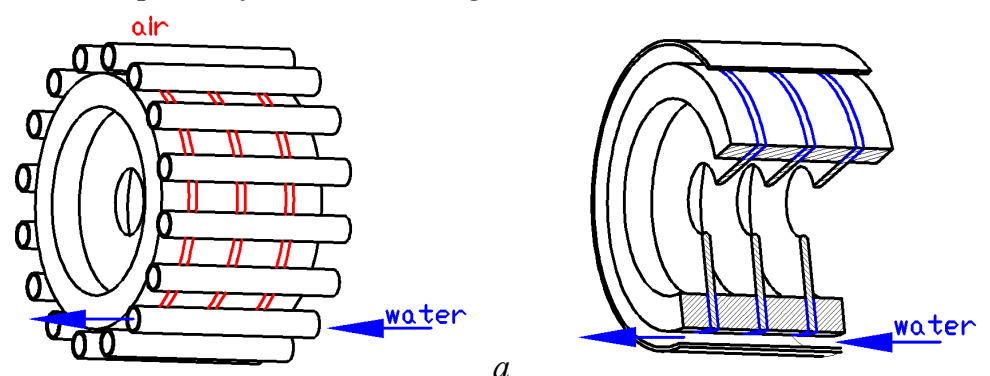

Fig. 1. Methods of thermal stabilization of linac accelerating sections with cooling tubes (a); the outside cooling (b); internal cooling channels (c).

Blue -water leaks; red-air leaks

\section{LEAK MODEL AND ACCEPTABLE LEAK RATE}

Assume the presence of a single leak in the form of a rectilinear cylindrical horizontal capillary of length $L$ and diameter $D$ (Fig. 2).

To begin, we assume that the capillary walls and the inner surface of the accelerating section are completely wetted by water. A stationary water flow in this case is possible when it leaves the capillary and spreads over the inner surface of the accelerating section (see Fig. 2,b). The same process will occur if the capillary is not wetted (but the walls of the accelerating section are wetted), if the water pressure in the cooling system is greater than the meniscus pressure e.g. $253312.5 \mathrm{~Pa}$ (2.5 atm) for $D=1 \mu \mathrm{m}$.

If the water pressure is not enough, then the water is blocked by the channel (see Fig. 2,c). The water flow
It should be noted that it is advisable to check the hydraulic, as well as gas tightness, by helium leak rate, which is associated with the undesirability of oxidizing pore surfaces with water, making it difficult to eliminate them by re-soldering. In this case, it is required to establish the ratio between the flows of gas and water through the existing pores. Despite the importance of the question of the necessary soldering tightness in the choice of the technology for manufacturing sections, there is no clear answer to it in the literature on accelerator technology. Here are some opinions on this matter will be given. into the accelerating section in this case will be limited by its evaporation from the meniscus, which at a limited number of leaks is much less than its desorption from the whole section inside and can be ignored.

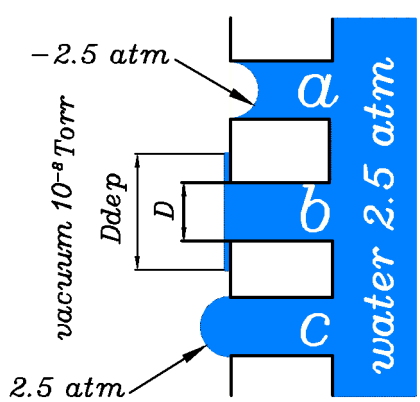

Fig. 2. Design models of hydraulic leaks: wettable capillary filling (a); spreading of water in a vacuum with full wetting (b); non wettable capillary (c) 
Thus, a water flow through a rectilinear cylindrical channel under the cooling water pressure can be taken as a model, without capillary effects (see Fig. 2,b).

We assume that this leak is the only one in the accelerating section, which is pumped out with a pumping speed $S=3 \cdot 10^{-2} \mathrm{~m}^{3} / \mathrm{s}(30 \mathrm{l} / \mathrm{s})$ at the inlet pipe pressure $P_{\mathrm{p}}=1.33 \cdot 10^{-6} \mathrm{~Pa}\left(10^{-8}\right.$ Torr $)$ equal to section pressure.

Water vapor in a vacuum satisfies the equation of state of an ideal gas. Therefore, in the stationary case, $P_{\mathrm{p}}=$ const, it create a flow of molecules into the pump $d N / \mathrm{d} t=\Delta P \cdot S / k T$, where $\Delta P-$ increase in pressure over a stationary level in the absence of leaks.

As a criterion for tightness, we accept $\Delta P=\xi P_{\mathrm{p}}$. Then the allowable flow of molecules will be:

$$
(d N / d t)_{\max }=\xi P_{\mathrm{p}} S / k T \text {. }
$$

The parameter $\xi$ is determined by the developer based on the requirements for the vacuum installation. The standard is $\xi=0.1$ [4]. However, in some cases, the tightness requirement can be reduced several times. For example, for the accelerator LU-10 which is being developed at the R\&D "Accelerator" NSC KIPT, we can assume $\xi=1$, which will increase the pressure in the accelerating section $P_{\mathrm{p}}$ from $10^{-8}$ up to $2 \cdot 10^{-8}$ Torr. Then $(\mathrm{d} N / \mathrm{d} t)_{\max }=9.88 \cdot 10^{12} \mathrm{c}^{-1}$

From the condition for water molecules $\left(\mathrm{d} N_{\mathrm{w}} / \mathrm{d} t\right)_{\max }=(\mathrm{d} N / \mathrm{d} t)_{\max }$, you can find the allowable water volumetric leak rate: $F=\left(d V_{\mathrm{w}} / \mathrm{d} t\right)_{\max }$ according to the equation:

$$
Q_{\max }=(d N / d t)_{\max }=n_{\mathrm{w}} F,
$$

where $n_{\mathrm{w}}$ - volumetric density of water molecules.

Substituting $n_{\mathrm{w}}=3.34 \cdot 10^{28} \mathrm{~m}^{-3}$ (at atmospheric pressure and a temperature of $20^{\circ} \mathrm{C}$ ), we obtain: $F=2.95 \cdot 10^{-16} \mathrm{~m}^{3} / \mathrm{s}$. If $D$ is the channel diameter, and $v-$ the cross-sectional average water speed, then

$$
v=4 F / \pi D^{2} .
$$

By Reynolds number, $\operatorname{Re}=4 \rho F /(\pi D \eta)$, where $\rho$ is water density, and $\eta-$ viscosity, we find the minimal diameter $D_{\min }$ for laminar flow, $\operatorname{Re} \leq \operatorname{Re}_{\mathrm{cr}}$ :

$$
D_{\min }=\frac{4 \rho F}{\pi \eta \operatorname{Re}_{c r}} .
$$

Using $\operatorname{Re}_{\mathrm{cr}}=2300$ and water physical parameters at a temperature of $40^{\circ} \mathrm{C}$, equal to the temperature of the section, we obtain $D_{\min }=2.48 \cdot 10^{-13} \mathrm{~m}$. Therefore, at $D \geq 2.48 \cdot 10^{-13} \mathrm{~m}$ and an admissible volumetric leak rate $F$, the water flow will be laminar.

It's obvious that minimal channel diameter $D_{\min }$, in which water has a fluidity property, is $3 D_{\mathrm{w}}$, where $D_{\mathrm{w}}$ is the diameter of the water molecule. Seeing $D_{\mathrm{w}}=$ $3.1 \cdot 10^{-10} \mathrm{~m}$ (from the Avogadro number and water density at normal conditions) we can conclude that, the flow regime will be laminar for any diameter of the hydraulic leak channel when the water flow is below the permissible.

Then, in order to calculate the allowable channel diameter, we can use the Poiseuille formula connecting the volumetric leak rate through a cylindrical channel of length $L$ with its pressure drop $\Delta P[5]$ :

$$
F=\frac{\pi D^{4}}{128 \eta} \cdot \frac{\Delta P}{L} .
$$

Obviously, $\Delta P=P_{w}-P_{p}$, where $P_{w}-$ is the the water pressure in the cooling system. Typically, $P_{w}$ is above atmospheric pressure $P$, therefore $P_{w}=\kappa P$, where $\kappa>1$. Due to the smallness of $P_{\mathrm{p}} / \kappa P, \Delta P \approx \kappa P$. Then from (5), taking into account (2), we obtain:

$$
D_{\max }=\left(Q_{\max } \cdot \frac{128 \eta L}{\pi \cdot \kappa p \cdot n_{w}}\right)^{\frac{1}{4}} .
$$

Assuming water viscosity at $40^{\circ} \mathrm{C}, \eta=6.6 \cdot 10^{-4} \mathrm{~Pa} \cdot \mathrm{s}$ and $L=3 \cdot 10^{-3} \mathrm{~m}, P=101325 \mathrm{~Pa}(1 \mathrm{~atm}), \kappa=3$ (e.g. LU-10 NSC KIPT), we obtain: $D_{\max }=5.3 \cdot 10^{-7} \mathrm{~m}$.

In order to test the hydraulic tightness of the accelerating section for helium, we calculate the helium leak rate through this channel. At an average channel pressure equal to $P / 2$, the mean free path of helium molecules is $\lambda=3.75 \cdot 10^{-7} \mathrm{~m}[6]$, then the Knudsen number is: $\lambda / D_{\max }=0.7>1 / 3$, which corresponds to the molecular flow regime [4], at which the flow of molecules according to [7] is equal to:

$$
Q=\frac{d N}{d t}=\frac{1}{3}\left(\frac{\pi}{2 m k T}\right)^{1 / 2} \frac{D^{3}}{L} \Delta P .
$$

Substituting in (7), $\Delta P=101325 \mathrm{~Pa} \quad(1 \mathrm{~atm})$, $m=m_{\mathrm{He}}=6.6 \cdot 10^{-27} \mathrm{~kg}$ and $D=D_{\max }$, we obtain for helium: $\left(Q_{\mathrm{He}}\right)_{\max }=4 \cdot 10^{11} \mathrm{c}^{-1}$.

Using the leak units accepted in the vacuum technique we find the required sensitivity of the leak detector: $P d V_{\mathrm{He}} d t=k T\left(Q_{H e}\right)_{\max }=1.63 \cdot 10^{-9}\left(\mathrm{~Pa} \cdot \mathrm{m}^{3}\right) / \mathrm{s}\left(1.2 \cdot 10^{-8}\right.$ (Torr $\left.\left.\cdot \mathrm{l}\right) / \mathrm{s}\right)$.

For air (nitrogen) from (7) we find: $\left(Q_{N_{2}}\right)_{\max } /(Q)_{\max }=0.015$.

Thus, the use of cooling systems with internal hydraulic channels or external water cooling of the section requires at least a $1 / 0.015=66$ times increasing in air tightness of soldering compared to sections cooled by the water flow through the outer tubes.

\section{PERMISSIBLE SECTION POLLUTION}

It is obvious that impurities dissolved in water can form a dry residue during its evaporation. The amount of sediment at an acceptable but prolonged leakage can be significant, which creates the question of its effect on the electrodynamics' characteristics and electrical breakdown limit of the accelerating sections. An important circumstance, when considering this issue, is that the area of this pollution is limited by the condition of a balance between the amount of evaporation and leakage of water: $q s=(d N / d t)_{\max }$, where $q$ - the flux density of evaporating molecules, and $s$ is the spreading area. To assess the scale of this phenomenon, we assume uniform spreading when the sediment spot will have the form of a ring with a diameter of $D_{\text {dep }}$ (see Fig. 2,b).

For conservation electrical breakdown limit is required that $D_{\text {dep }}<<D_{\text {coil }} / 2$, where $D_{\text {coil }}$ is the internal diameter of the resonant cell of the accelerating section. Then also $D_{\text {dep }}{ }^{2}<<\left(D_{\text {coil }} / 2\right)^{2}$, which at the same time ensures the conservation of electrodynamics' characteristics (microwave losses and phase velocity).

Using the Knudsen-Hertz equation [8] for $P_{\mathrm{p}}<<P_{\mathrm{s}}$, we find:

$$
q=P_{s} \alpha\left(8 \pi k T_{w} m_{w}\right)^{-0.5} .
$$

Then from the flow balance equation: 
$q \pi\left(D_{d e p}^{2}-D_{\max }^{2}\right) / 4=Q_{\max }$, we obtain:

$$
D_{d e p}=\left[\frac{4 Q_{\max }}{\pi q}+D_{\max }^{2}\right]^{0.5} .
$$

Substituting the accommodation coefficient $\alpha=0.045[8], P_{\mathrm{s}}=7520 \mathrm{~Pa}\left(40^{\circ} \mathrm{C}\right)$ and using a typical value for the $S$-band acceleration sections $D_{\text {coil }}=0.08 \mathrm{~m}$, we obtain: $D_{\text {dep }} / D_{\text {coil }}=2 \cdot 10^{-5}<<1$.

Therefore, leak criterion (1) for typical accelerating sections also satisfies the criterion of their permissible pollution with cooling water.

\section{DISCUSSION}

The above results were obtained with a single straightforward leak in the accelerating section. In practice tightness is controlled by the total helium leak rate through an unknown number and length leaks.

Using (2), (5), (7), we can find the flow ratio of gas molecules through one capillary $Q_{\mathrm{g}}$ with a diameter $D_{\max }$ to that admissible by the hydraulic tightness criterion $Q_{\max }$ :

$$
\left(\frac{Q_{g}}{Q_{\max }}\right)_{1}=\frac{128 \eta}{3(2 \pi m k T)^{0.5} n_{w}} \cdot \frac{1}{D_{\max }} .
$$

Substituting $D_{\max }$ from (6), relation (10) can be represented as:

$$
\left(Q_{g}\right)_{1}=\frac{A Q_{\max }^{0.75}}{L^{0.25}},
$$

where $A$ is a constant independent of the leak geometry.

Therefore, the allowable helium leak rate obtained from (7) for a rectilinear channel $L=3 \mathrm{~mm}$ must be reduced in the presence of winding channel with the total length of straight line segments $L_{t}>>3 \mathrm{~mm}$. A probable limitation, apparently, can be considered $L_{t} \leq 100 L$. Then the recommended tightness in helium will be $P d V_{\mathrm{He}} / d t \leq 5 \cdot 10^{-10}\left(\mathrm{~Pa} \cdot \mathrm{m}^{3}\right) / \mathrm{s}\left(3.8 \cdot 10^{-9}\right.$ (Torr $\left.\left.\cdot 1\right) / \mathrm{s}\right)$.

It also follows from (11) that a decrease in $Q_{\max }$ by a factor of 100, for example for a linac with a photoinjector where $P_{\mathrm{p}}=10^{-10}$ Torr requires an increase in the recommended tightness obtained above to the level of $P d V_{\mathrm{He}} / d t=1.58 \cdot 10^{-11}\left(\mathrm{~Pa} \cdot \mathrm{m}^{3}\right) / \mathrm{s}$. The obtained value is within the sensitivity range of serial leak detectors.

Let us estimate the error in the approximation of a single leak.

For an array of $n$ leaks:

$$
\left(\frac{Q_{g}}{Q_{\max }}\right)_{n}=\frac{128 \eta}{3(2 \pi m k T)^{0.5} n_{w}} \cdot \frac{\sum_{1}^{n} D_{i}^{3} / D_{\max }^{3}}{D_{\max } \sum_{1}^{n} D_{i}^{4} / D_{\max }^{4}} .
$$

From (10) and (12) considering $\left.Q_{\max }\right)_{\mathrm{n}}=\left(Q_{\max }\right)_{1}=\left(Q_{\max }\right)$ and $D_{i} / D_{\max } \leq 1$, we get

$$
\delta=\frac{\left(Q_{g}\right)_{1}}{\left(Q_{g}\right)_{n}} \leq 1
$$

It follows from (13) that the assumption of a single leak gives an underestimated value of the permissible gas leak rate which guarantees hydraulic tightness in the presence of an array of leaks.

The permissible error $\delta$ depends on the position of the maximum of the leak distribution function on the diameter of their channel, which is generally unknown.
For example, with a uniform distribution with a constant step $D_{\mathrm{i}}=i D_{\max } / n$ :

$$
\left(\frac{Q_{g}}{Q_{\max }}\right)_{n}=\frac{128 \eta}{3(2 \pi m k T)^{0.5} n_{w}} \cdot \frac{\sum_{1}^{n} i^{3}}{D_{\max } \sum_{1}^{n} i^{4}} .
$$

Using the sum values [9] in (14), we get:

$$
\begin{gathered}
\left(\frac{Q_{g}}{Q_{\max }}\right)_{n}=\frac{128 \eta}{3(2 \pi m k T)^{0.5} n_{w}} \cdot \frac{30}{4 D_{\max }} \cdot \frac{n^{2}(n+1)}{(2 n+1)\left(3 n^{2}+3 n-1\right)}, \\
\delta=\frac{4}{30} \cdot \frac{(2 n+1)\left(3 n^{2}+3 n-1\right)}{n^{2}(n+1)} .
\end{gathered}
$$

For $n>>1, \delta \approx 0.8$.

Relation (15) does not depend on the geometry of capillaries therefore it remains valid also for winding channels.

\section{CONCLUSIONS}

From obtained results it follows that the dominant factor in the process of leakage into vacuum is the ambient density but not viscosity. So, despite the difference in the viscosity of water and air by 20 times, the difference in the density of their molecules by 3 orders of magnitude leads to an increase in the water molecules leak rate by 66 times, compared with the air leak rate.

Despite the increased tightness requirements, contacted with cooling water accelerating sections can be tested with serial helium leak detectors therefore, they are quite reliable in operation.

\section{REFERENCES}

1. N.G. Ganzha et al. On the issue of choosing heat exchange surfaces for elements of an accelerating structure with a high level of high-frequency losses in metal // Problems of Atomic Science and Technology. Series "Physics Experiment Technique". 1984, № 1, p. 54-56.

2. V.F. Zhiglo, V.A. Kushnir, V.V. Mytrochenko, K.Yu. Kramarenko. Cooling Systems for the LU-10 Accelerating section // Problems of Atomic Science and Technology. Series "Nuclear Physics Investigations”. 2015, № 6, p. 18-22.

3. K. Dunkel, C. Piel, H.V. Vogel, P. Stein. Production of S-band Accelerating Structures // Proceedings of LINAC 2004, Lubeck, Germany, p. 666-668.

4. A.B. Zeitlin. Steam Jet Vacuum Pumps. MoscowLeningrad: "Energy", 1965, 400 p. (in Russian).

5. A.K. Kikoin, I.K. Kikoin. Molecular Physics. M.: "Nauka", 1974, 478 p. (in Russian).

6. G. Bird. Molecular gas dynamics. M.: "Mir", 1981, 316 p. (in Russian).

7. D.V. Sivukhin. General course of physics, v. 2. Thermodynamics and molecular physics. M.: "Nauka", 1975, 552 p. (in Russian).

8. O. Knake, I.N. Stranskin. Evaporation mechanism // Uspekhi Phys. Nauk. 1959, v. LXVIII, № 2, p. 261-305 (in Russian).

9. I.N. Bronstein, K.A. Semendyaev. Handbook of Mathematics. M.: "Science", 1980, 974 p.

Article received 05.05.2021 


\section{О ГАЗОВОЙ И ГИДРАВЛИЧЕСКОЙ ГЕРМЕТИЧНОСТИ УСКОРЯЮЩИХ СЕКЦИЙ ЛУЭ}

\section{В.Ф. Жигло}

Приведена методика расчета требуемой герметичности пайки ускоряющих секций ЛУЭ, охлаждаемых водой, и контроля их гидравлической герметичности по общему натеканию гелия. Рассмотрены три типа систем охлаждения: потоком воды в трубках, напаянных на наружной поверхности секций, потоком воды по наружной поверхности и по внутренним каналам охлаждения секций. Показано, что контакт поверхности ускоряющих секций с охлаждающей водой требует повышения герметичности их пайки, по крайней мере, в 66 раз. В качестве примера приведены требования к герметичности ускоряющих секций ускорителя ЛУ-10, разрабатываемого в ННЦ ХФТИ.

\section{ПРО ГАЗОВУ ТА ВОДЯНУ ГЕРМЕТИЧНІСТЬ ПРИСКОРЮЮЧИХ СЕКЦЙ ЛПЕ}

\section{В.Ф. Жигло}

Наведена методика розрахунку герметичності пайки прискорюючих секцій ЛПЕ, що охолоджуються водою, і оцінки герметичності за загальним натіканням гелію в прискорюючу секцію. Розглянуті три типи систем охолодження: потоком води в трубках, напаяних на зовнішній поверхності секцій, потоком води по зовнішній поверхні і по внутрішніх каналах охолодження секцій. Показано, що контакт поверхні прискорюючих секцій з охолоджувальною водою вимагає підвищення герметичності їх пайки, принаймні, в 66 разів. Як приклад наведені вимоги до герметичності прискорюючих секцій прискорювача ЛП-10, що розроблюється в ННЦ ХФТІ. 